\section{Summary}

Eight adult patients with acute transient arthritis of the hip are described. Follow-up periods varied from 9 to 54 months; average, 24 months.

It is important to exclude acute bacterial arthritis by aspiration of the hip-joint.

Two patients are diagnosed confidently, and one provisionally, as cases of rheumatoid arthritis. One patient is diagnosed as a case of rheumatoid arthritis (palindromic) and one as "palindromic rheumatism." One patient possibly suffered from Reiter's syndrome. As yet two patients remain undiagnosed.

We thank Dr. R. M. Mason for kindly reading this paper and for several helpful suggestions.

\section{REFERENCES}

Forestier, J., Arlet, J., and Jacqueline, F. (1951). Rev. Rheum. 18, 304.

Hart, F. D., and Golding, J. R. (1960). Brit. med. J., 1, 1594.

Hench, P. S., and Rosenberg, E. F. (1941). Proc. Mayo Clin., 16, 808.

Kellgren, J. H., Ball, J., Fairbrother, R. W., and Barnes, K. L. (1958). Brit. med. J., 1, 1193.

Jones, G. B. (1955). J. Bone Jt Surg., 37B, 448.

Ropes, M. W., Bennett, G. A., Cobb, S., Jacox, R., and Jessar, R. A. (1956). Bull. rheum. Dis., 7, 121 .

Rose, H. M., Ragan, C., Pearce, E., and Lipman, M. O. (1948). Proc. Soc. exp. Biol. (N.Y.), 68, 1.

Short, C. L., Bauer, W., and Reynolds, W. E. (1957) Rheumatoid Arthritis, p. 197. Harvard Univ. Press, Cambridge, Mass.

Singer, J. H., and Plotz, C. M. (1956). Amer. J. Med., 21, 888.

Steinberg, V. L. (1960). Brit. med. J., 1, 1600.

\title{
A FATAL CASE OF PROGRESSive VACCINIA
}

BY

\section{J. H. CONNOLLY, M.D. G. W. A. DICK, M.D., D.Sc., F.R.C.P.Ed., M.R.C.P \\ Department of Microbiology, Queen's University of Belfast}

AND

\section{M. B. FIELD, M.D., M.R.C.P.Ed., D.C.H. Belfast City Hospital}

Progressive vaccinia (vaccinia necrosum, vaccinia gangrenosa) is a rare complication of vaccination which has recently been reviewed by Kempe (1960) and by Erichson and McNamara (1961). The present case is reported because of the failure of passively transferred antibody or $N$-methylisatin $\beta$-thiosemicarbazone (compound 33T57) to influence the course of the disease.

\section{Case History}

The patient, the second child of healthy parents (whose first baby had died soon after birth with a spina bifida), was vaccinated against smallpox by multiple pressure over the left deltoid region at the age of 10 months. The primary vaccination began to develop normally, but at about the same time a papule appeared on the sole of her left foot which, like the primary lesion, became vesicular in six days. These vesicles increased in size, and when we saw the child four months after vaccination the posterior half of the sole of the left foot was covered by a crusted lesion which extended on to the lateral side and also medially as far as the malleolus. The edge of this lesion was vesiculated and surrounded by a reddish areola. On the outer side of the left arm there was an irregular lesion $5 \mathrm{~cm}$. in diameter with an extension towards the shoulder

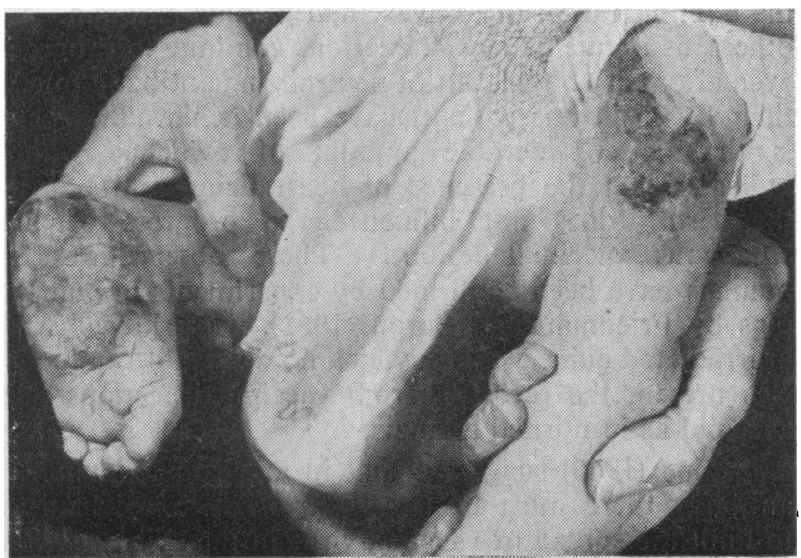

Frg. 1.-Vaccinial lesions 18 weeks after vaccination. consisting of raw and crusted areas with a rolled vesicular edge and a surrounding wide zone of erythema (Fig. 1).

Vaccinia virus was recovered from the lesions on the arm and the foot. The child's serum taken at this time contained no demonstrable neutralizing or haemagglutinationinhibiting antibody to vaccinia virus. The serum gammaglobulin was $0.51 \mathrm{~g} . / 100 \mathrm{ml}$., calculated from paper electrophoresis of the serum (Oberman, Gregory, Burke, Ross, and Rice, 1956). Examination of the blood cells showed a hypochromic anaemia ( $\mathrm{Hb} 6.6 \mathrm{~g} . / 100 \mathrm{ml}$.) of the irondeficiency type and a lymphopenia.

\section{Treatment}

The treatment of vaccinial complications with gammaglobulin or immune serum has been discussed by Kempe (1960). We began treatment of our patient with intramuscular injections of antivaccinial gamma-globulin (batch EPG 101) and a transfusion of fresh whole blood from an immune donor. The antibody levels and the gammaglobulin which developed in the child's serum are shown in Table $I$.

TABLE I

\begin{tabular}{|c|c|c|c|c|c|}
\hline \multirow{2}{*}{$\begin{array}{l}\text { Day of } \\
\text { Lesions }\end{array}$} & \multirow{2}{*}{ Procedure } & \multirow{2}{*}{$\begin{array}{c}\text { Material } \\
\text { Tested }\end{array}$} & \multicolumn{2}{|c|}{ Antibody Titres* } & \multirow{2}{*}{$\begin{array}{c}\text { Serum } \\
\boldsymbol{\gamma} \text {-globulin } \\
(\mathrm{g.} / 100 \mathrm{ml} .)\end{array}$} \\
\hline & & & H.I. $\dagger$ & Neut. & \\
\hline $\begin{array}{l}126 \\
127\end{array}$ & $\begin{array}{l}\text { Test } \\
\text { 1 g. } \gamma \text {-globulin }\end{array}$ & $\begin{array}{l}\text { Patient's serum } \\
\gamma \text {-Globulin }\end{array}$ & $\begin{array}{l}<5 \\
640\end{array}$ & 1,605 & 0.51 \\
\hline $\begin{array}{l}129 \\
130\end{array}$ & Test " " & Patient's serum & $\frac{1}{5}$ & $=$ & $0 . \overline{55}$ \\
\hline 131 & $300 \mathrm{ml}$. blood & Donor's ", & 80 & - & $\overline{0.78}$ \\
\hline & & & & & \\
\hline
\end{tabular}

* The antibody titres are the highest effective dilutions of serum before the addition of virus.

+ Haemagglutination inhibition, using the method described by Kempe (1956).

$\ddagger$ Neutralization tests were kindly carried out by Professor A. W. Downie, University of Liverpool.

A small haematoma occurred on the back of the child's hand where the transfusion needle was placed, and 5,000 units of lyophilized crystalline alpha-chymotrypsin was given orally three times daily for five days to increase the rate of absorption. On the seventh day after the transfusion the child developed a fever of $103^{\circ} \mathrm{F} .\left(39.4^{\circ} \mathrm{C}\right.$.), and on the following two days it was $105^{\circ} \mathrm{F}$. $\left(40.6^{\circ} \mathrm{C}\right.$.), after which it fell to normal. It is not known whether the febrile 
reaction was due to the transfused white cells or the alphachymotrypsin, but there was a marked improvement in the baby's condition after the transfusion, probably due to the correction of the anaemia $(\mathrm{Hb} 10.1 \mathrm{~g} . / 100 \mathrm{ml}$.) and the lesions looked drier for a few days. During this febrile period the baby developed an urticarial rash on the face and body which faded after four days. By the 12th day of treatment an H.I. titre of $1: 20$ and a total gamma-globulin of $0.78 \mathrm{~g} . / 100 \mathrm{ml}$. had been obtained in the patient's serum. Further injections of $1 \mathrm{~g}$. of antivaccinial gamma-globulin were given on the 12th and 15th days. In addition, for the first 11 days of treatment pooled serum from four recently vaccinated individuals was applied four-hourly to the lesions.

Over the next few weeks the lesions on the arm extended on to the shoulder and the spreading edge had increased in size. The foot lesion, however, had not progressed. Since antibody therapy did not seem to be retarding the slow progression of the lesions on the shoulder it was decided to try the effect of $N$-methylisatin $\beta$-thiosemicarbazone, which was kindly supplied by Dr. D. J. Bauer, of the Wellcome Laboratories of Tropical Medicine, London. This drug had been shown to be effective against vaccinia in mice when given orally (Bauer and Sadler, 1960). However, because of its potential toxicity, we decided to try it first as a suspension of $10 \%$ powder in a cream which was applied four times daily to the lesions on the arm. The lesions were now 147 days old. During the first week of this treatment there was no evidence of toxicity. Urine samples were normal, bilirubin was absent, and no excess urobilinogen or urobilin was present. The cream was then applied also to the foot and the baby was allowed to go home. On the 10th day of treatment with this drug the mother noted the development of a diffuse rash on the baby's skin but continued using the cream for a further 15 days, when she was again seen by us with a blotchy erythematous rash on the hands, feet, back, and abdomen, and the mother said that the baby's hair was beginning to fall out. The drug was stopped and the rash faded. It was obvious that there had been no arrest of the spread of the lesions on the arm and shoulder, and a new lesion had developed on the shoulder and also on the right thumb, presumably as a result of autoinoculation.

After this treatment the child was given $1 \mathrm{~g}$. of antivaccinial gamma-globulin (batch EPG 101) daily for two days and 1 g. 15 and 26 days later. When her serum was tested 11 days after the last dose of gamma-globulin it was found that the H.I. titre was only $1: 5$ and the serum gammaglobulin had dropped to $0.38 \mathrm{~g} . / 100 \mathrm{ml}$.

When the lesions had been present for 201 days the effect of interferon was tried. This was kindly supplied by Dr. A. J. Beale, of Glaxo Laboratories Ltd., Stoke Poges, as cynomolgus monkey interferon batch $106 \mathrm{ACD} / 1$ st harvest. It had a titre of $1: 50$ against an E.C.B.O.* virus (strain M 6) in monkey-kidney cells before filtration through a $0.45-\mu$ membrane. Four ml. of this interferon was infiltrated intracutaneously and subcutaneously by multiple injections around the spreading edge of one area of the lesion on the chest. During the next 10 days the lesion continued to spread at a similar rate over the area of the skin where interferon had been injected as on the untreated skin.

In an attempt to try to obtain high levels of antibody we decided to give large doses of antivaccinial gamma-globulin and immune serum. Accordingly, $10 \mathrm{~g}$. of antivaccinial gamma-globulin (batch EPG 138) was given by intramuscular injection over a period of five days, followed three days later by an intravenous transfusion of $400 \mathrm{ml}$. of pooled serum from two recently revaccinated colleagues. The antibody levels and the gamma-globulin which developed in the child's serum are shown in Table II.

In spite of this amount of antibody and further maintenance doses of gamma-globulin the lesions continued to spread on the chest and shoulder as seen in Fig. 2. The foot lesion showed little change, but the lesion on the thumb

*Enteric cytopathogenic bovine orphan virus.

\begin{tabular}{|c|c|c|c|c|c|}
\hline \multirow{2}{*}{$\begin{array}{l}\text { Day of } \\
\text { Lesions }\end{array}$} & \multirow{2}{*}{ Procedure } & \multirow{2}{*}{$\begin{array}{l}\text { Material } \\
\text { Tested }\end{array}$} & \multicolumn{2}{|c|}{ Antibody Titres } & \multirow{2}{*}{ 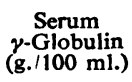 } \\
\hline & & & H.I. & Neut. & \\
\hline $\begin{array}{c}212 \\
216-220 \\
222 \\
223 \\
226\end{array}$ & $\begin{array}{l}\text { Test } \\
10 \mathrm{~g} \cdot \boldsymbol{\gamma} \text {-globulin } \\
\text { Test } \\
400 \mathrm{ml} . \text { serum } \\
\text { Test }\end{array}$ & $\begin{array}{l}\text { Patient's serum } \\
\text { y-Globulin } \\
\text { Patient's serum } \\
\text { Donor's ", } \\
\text { Patient's , }\end{array}$ & $\begin{array}{c}5 \\
640 \\
20 \\
40 \text { and } \\
80 \\
40\end{array}$ & $\begin{array}{r}3,200 \\
= \\
>125\end{array}$ & $\begin{array}{c}0.47 \\
0.60 \\
-\end{array}$ \\
\hline
\end{tabular}

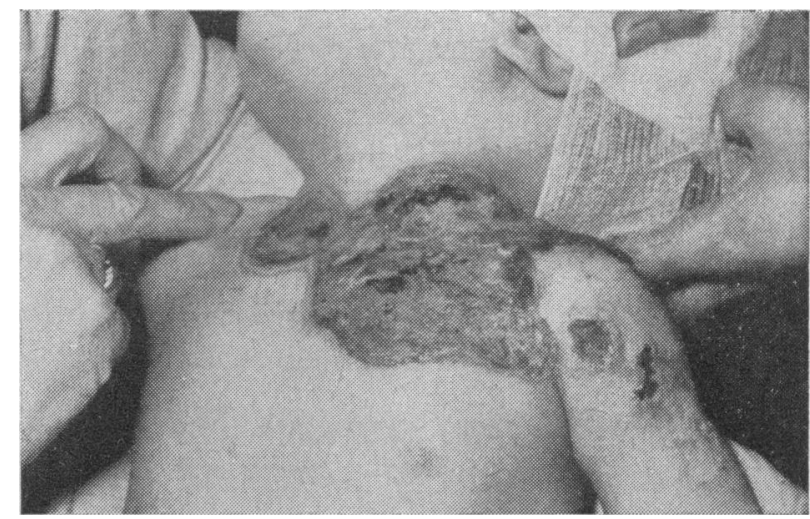

Fig. 2.-Vaccinial lesions 36 weeks after vaccination.

had extended beyond the interphalangeal joint and the nailbed was black.

On the 265th day of the lesions we decided to try the effect of $N$-methylisatin $\beta$-thiosemicarbazone by mouth in a dose of $250 \mathrm{mg}$. six-hourly for 14 days. After this treatment the lesions continued to spread and the child now looked ill; her hair was thin, and the liver was hard and enlarged three fingerbreadths below the costal margin. The abdomen was enlarged and some free fluid was present. The white-cell count was $8,150 / \mathrm{c} . \mathrm{mm}$. and the lymphopenia was still present. Two weeks later she developed bronchopneumonia and died on the 302 nd day after being vaccinated.

\section{Discussion}

Neutralizing antibody levels after primary vaccination are about $1: 5$ to $1: 10$ (A. W. Downie, personal communication), yet our patient had no detectable antibody in spite of large areas of virus multiplication. The serum gamma-globulin was low in this child before treatment began and later fell to lower levels before being restored with large doses of gamma-globulin. While the majority of children with hypogammaglobulinaemia react normally to smallpox vaccination (Good and Varco, 1955 ; Kempe, 1960) some develop complications such as progressive vaccinia but survive after the administration of antivaccinial gamma-globulin. In others, as in our patient, the lesions continue to progress even after very high levels of neutralizing antibody (more than $1: 125$ in this patient) have been achieved. There is thus a considerable amount of evidence which indicates that the presence of neutralizing antibody in the serum does not influence the progress of the cutaneous vaccinial lesions. These observations in humans have been confirmed by experiments in guineapigs by Friedman and Baron (1961), who showed that in irradiated guinea-pigs in which no detectable antibody was present the recovery from vaccinia infections was as rapid as in normal animals.

Kempe (1960) suggested that in addition to humoral antibody there must be a cellular defence mechanism to limit the spread of vaccinia virus in the skin and that this might be delayed hypersensitivity. This hypothesis 
was recently investigated by Turk, Allison, and Oxman (1962) in guinea-pigs. Their experiments showed that there was little difference in the quantity of virus which multiplied in animals devoid of circulating antibody with delayed hypersensitivity compared with normal animals, and suggested that the spread of vaccinia virus is normally limited by factors, other than antibody and delayed hypersensitivity, among which is interferon. Although vaccinia virus is sensitive to interferon (Andrews, 1961) there is nevertheless no evidence that the immune status which an individual develops after vaccination is due to an increased amount of interferon in his skin. Our failure to influence the progress of the lesions in our patient with interferon was perhaps due to the low titre of interferon available at the time, and interferon should certainly be tried in future cases of progressive vaccinia.

It is remarkable that the foot lesion remained static for nine months while the arm and thumb lesions progressed, yet in spite of an actively spreading edge the early arm lesions healed with little scarring.

The only occasion on which there was any apparent sign of remission in the patient was a few days after the fresh blood transfusion during a period of pyrexia. It is possible that this temporary remission may have been due to the transfer of a delayed type of hypersensitivity by the white cells in the donor's blood. In any event it would seem that in future cases of progressive vaccinia, in addition to providing passive antibody, hypersensitivity to vaccinia might be induced by local injection of disrupted white cells or lymph-node suspensions from recently vaccinated individuals as suggested by Kempe (personal communication). The injection of viable immunologically competent cells may cause runt disease (Nisbet and Heslop, 1962), but this can be avoided by using white-cell extracts, which have been shown to be effective in transferring delayed type hypersensitivity to humans (Lawrence, 1960). Alternatively, sensitization might be induced by injecting vaccinia virus which had been inactivated by ultra-violet radiation or formalin.

We considered the possibility of surgical removal of the lesions in our patient but were dissuaded from this by the very slow progress of the condition, by the fact that the healed areas showed little scarring, and by the hope that the child might eventually overcome the infection.

There was no evidence that $N$-methylisatin $\beta$-thiosemicarbazone had any effect in controlling the progress of the disease or the cutaneous lesions, and the drug appeared to be toxic. This compound has caused no abnormalities when subjected to chronic toxicity tests in animals and no ill effects were observed in two adult human volunteers to whom the drug was given (Bauer and Goodwin, 1962), nor in an adult patient with leukaemia who developed progressive vaccinia (Davidson and Hayhoe, 1962).

\section{Summary}

The failure of large doses of antivaccinial gammaglobulin or $N$-methylisatin $\beta$-thiosemicarbazone to control the progress of infection in a fatal case of progressive vaccinia is described. Possible measures for treating further cases are discussed.

We thank Dr. R. Hall, who looked after this patient initially, and Dr. I. J. Carré for medical care during the first hospital admission. Our thanks are also due to Dr. J. C. McDonald, of the Public Health Laboratory Service, Colindale, for supplies of antivaccinial gamma-globulin, and to Mr. T. Macfarlane, F.I.M.L.T., for carrying out the serum electrophoresis. We are indebted to Dr. D. I. H. Simpson and Mr. D. Gay for donating immune blood.

\section{REFERENCES}

Andrews, R. D. (1961). Brit. med. J., 1, 1728.

Bauer, D. J., and Goodwin, L. G. (1962). Ibid., 1, 716.

and Sadler, P. W. (1960). Lancet, 1, 1110.

Davidson, E., and Hayhoe, F. G. J. (1962). Brit. med. J., 1, 790 Erichson, R. B., and McNamara, M. J. (1961). Ann. intern. Med., 55, 491.

Friedman, R. M., and Baron, S. (1961). J. Immunol., 87, 379.

Good, R. A., and Varco, R. L. (1955). J.-Lancet, 75, 245.

Kempe, C. H. (1956). In Diagnostic Procedures for Virus and Rickettsial Diseases, 2nd ed., p. 354. American Public Health Association, New York. Health Association, New Yo
(1960). Pediatrics, 26, 176.

Lawrence, H. S. (1960). In Cellular Aspects of Immunity, edited by G. E. W. Wolstenholme and M. O'Connor, p. 243. Churchill, London.

Nisbet, N. W., and Heslop, B. F. (1962). Brit. med. J., 1, 129, 206.

Oberman. J. W., Gregory, K. O., Burke, F. G., Ross, S., and Rice. E. C."(1956). New Engl. J. Med., 255, 743.

Turk, J. L., Allison, A. C., and Oxman, M. N. (1962). Lancet, 1, 405 .

\section{Preliminary Communications}

\section{Eczema Vaccinatum Treated with $N$-Methylisatin $\beta$-Thiosemicarbazone}

Much work has been done in recent years on the chemotherapy of the pox virus infections with isatin $\beta$-thiosemicarbazone and its derivatives. The compound itself will confer protection against death and development of symptoms in mice infected intracerebrally with $100,000 \mathrm{LD}_{50}$ of vaccinia virus (Bauer, 1955), and is equally effective against rabbit-pox virus (Bauer and Sheffield, 1959). A number of derivatives have been found with antiviral activity greater than that of isatin $\beta$-thiosemicarbazone itself (Bauer and Sadler, 1960a); of these, the $N$-ethyl derivative has been found to be active in mice infected with alastrim virus (Bauer and Sadler, 1960b), and the same compound and a number of others have been found to possess antiviral activity in mice infected with variola major virus (Bauer et al., 1962). The antiviral activities observed have in all cases been sufficiently great to indicate that some of these compounds might be of use in the specific chemotherapy of smallpox and vaccinia infection in man, and in the present communication an account is given of the use of $N$-methylisatin $\beta$-thiosemicarbazone (compound 33T57) in the treatment of eczema vaccinatum.

\section{CASE REPORT}

The patient is a boy born on July 7, 1961, who had suffered from infantile eczema since the age of 6 weeks ; at the age of $4 \frac{1}{2}$ months he was seen by a consultant dermatologist (Dr. J. B. MacMillan), and on treatment with a steroid-containing cream the lesions cleared. He was not vaccinated, but on January 18, 1962, both parents were successfully vaccinated, the mother having a primary vaccination, the father a secondary vaccinia with the immune accelerated reaction. On January 30 two small pustules appeared on the baby's scalp ; these were irritable, and the parents applied some of the steroid cream previously prescribed for the eczema. Within three days typical vaccinia lesions appeared all over the scalp and became 